\title{
CASES ONTO THEMSELVES? THEORY AND RESEARCH ON EX-SOCIALIST URBAN ENVIRONMENTS
}

\begin{abstract}
SJÖBERG, Ö. (2014): Cases onto themselves? Theory and research on ex-socialist urban environments. Geografie, 119, No. 4, pp. 299-319. - Although the contribution of geographers to post-socialist urban studies has shown considerable vitality and resulted in a great volume of research, its impact on urban studies as a general field of inquiry is neither proportionate to the momentous changes since 1989 nor to the volume of research that has found its way into the literature. The entire field punches below its weight and, despite recent claims to the contrary, the prominence and visibility of this line of research beyond the confines of established communities of scholars working in the field of socialist and post-socialist urban studies remains insubstantial. This has been pointed out by scholars of a post-colonial bent, who argue that in order to move forward both the alleged parochialism and empiricism of much current geographical work on post-socialist cities and the deference to hegemonic strands of Westerns urban theory need to be shed. This paper attempts to put these claims in perspective, suggesting that while some of the problems decidedly issue from the manner in which of urban geographers themselves conduct and report research on post-socialist cities, post-colonial theory might not be an ideal way forward.

KEY WORDS: European post-socialist cities - post-socialist urban studies - urban geography - post-colonialist theory - impact.
\end{abstract}

\section{Introduction}

Recently, two short, yet very different comments on the state of the art of post-socialist urban research have crossed my path. On the one hand, in an article in International Journal of Urban and Regional Research, the opening sentence assert that "[r]esearch on socio-spatial change in Central and Eastern European (CEE) cities is gradually making its way into urban theory" (Marcińczak et al. 2014, p. 1399), quoting a small number of high quality papers that purportedly are having an impact beyond the confines of post-socialist urban research. On the other, in a recent study on Warsaw, Grubbauer (2012, p. 38) is equally convinced that "research on post-socialist cities has yielded a rather closed body of literature, perceived as area studies from an outside perspective".

How wonderful would it have been if the former, more optimistic, statement on the current status of our research was true! Yet such an assertion is somewhat premature. For, while the contributions identified - on heteropolitanisation (Gentile, Tammaru, van Kempen 2012), segregation (Marcińczak, Musterd, Stępniak 2012) and multiple transitions (Sýkora, Bouzarovski 2012) - all have the potential to make some (if differentiated) impact beyond the community of scholars focusing on ex-socialist cities, it is yet to be seen if they will. Indeed, 
as will be discussed at some length in the following, even if true it does not necessarily imply that the full potential of current research on the socialist and post-socialist city is made use of or will be absorbed into the greater field of urban studies in such a fashion so as to meaningfully, let alone decisively, influence urban theory.

Does this imply that Grubbauer's more pessimistic account of the progress made is correct - and that, if correct, it will be to the exclusion of the more favourable development as sketched by Marcińczak and his collaborators? Not necessarily. First of all, precisely because the optimism seems somewhat premature, both statements can in fact be true - the one looking back on what has been achieved so far, the other looking forward to the impact studies of post-socialist urban change might have. Furthermore, Grubbauer's verdict is essentially empirical in nature, as is the contents of that opening sentence of the article in IJURR. Hence, they can be made subject of rather straightforward scrutiny, and results, again, might depend on when has much as how they are arrived at. ${ }^{1}$ Most importantly, there is no a priori reason to believe that either statement is necessarily true or false, be it for reasons of logic or structural contingencies that are beyond current or future use and evaluation to influence. But they do represent two very different views on how we should go about researching post-socialist cities.

Thus, although it is comforting to know that there is no reason to simply give up, the underlying issue, that of current and future contribution to urban studies more generally, remains unsolved. It also implies that there is a choice - or rather that there are several options, should you agree that students of postsocialist urban studies do not want to be marginalised or form a cosy coterie that is oblivious of an outside (scholarly) world that is equally ignorant of, or perhaps patently uninterested in, what is being done on the post-socialist city. This paper aims to contributing to the discussion on the options available, and it does so by critically assessing the two strands of research represented by the two opposing views identified above. The one is an increasingly sophisticated, yet predominantly empirical and geographically clearly demarcated line of research, the other takes a cue from post-colonialist theory.

In what follows, and starting from the assumption that post-socialist urban studies aspires to become more visible and to make an impact, following some brief preliminaries I will consider the current state of the art as epitomised by the two statements referred to at the beginning, that is the charge that we are not terribly good at designing or communicating research with a view of reaching out beyond our loosely defined community of post-socialist urban scholars. Then, allowing myself the luxury of assuming that research on post-socialist urbanism can in fact contribute to urban theory (and in this I am inspired by the late Musil 2005), in the third and fourth section I will set my eyes on the

\footnotetext{
As of 1 July 2014, and as assessed by Google Scholar and Web of Science combined (for a total of 45 unique citations in the scholarly literature, unpublished manuscripts excluded), two of the three articles referred to in the optimistic case had been quoted by someone outside the rather restricted circle of scholars focusing on the former socialist lands of Central, South-Eastern and Eastern Europe, and then only once each. But then again, it was but two years ago, or less, when these articles became publicly available.
} 
potential for doing so by joining, as some in our midst already have done, the critique that urban theory itself needs to be reconstituted. As this will result in the conclusion that it might not be the most effective strategy available, the final part of this contribution will outline a few possible lines of action which are better able to make use of the insights that our research on Central, South-Eastern and Eastern Europe yields for the benefit also of colleagues that set sight on other domains within urban studies, be it high theory or at least other geographical areas than the ones that we favour.

In order to do so, I will avail myself of a loosely formulated set of metaphors which allows me a possibility of breaking out of any disciplinary tribalism (Becker 1989) or other such expressions of parochialism as might tint our view of the field of post-socialist urban studies. I will do so by making use of basic concepts drawn from international economics rather than from anthropology. No conspiracy here; the positivistic taint of the former is not employed to entice readers into believing that what is being said is undeniably true. What I am after is simply a useful typology that will allow me a first cut at the issue. As with economies, where being large often (although not invariably) implies a relatively self-contained and inward-looking existence while smallness is more likely to result in openness to the outside world, also scholarly communities can be so characterised. Hence, as a preliminary observation and in recognition of the fact that students of post-socialist urbanism are but a small subset of the universe of urban scholars, I will frame my argument in terms of imports and exports. To this will be added that useful concept, so often overlooked in describing how one's own successful intellectual gains have been absorbed into cognate disciplines, of re-exports. This you may think of as a value-adding refining, assembly or repackaging operations, as you see fit.

\section{Isolated case studies - or making their way into urban theory?}

On this count it becomes quite obvious that the notion, implied by the quote from Grubbauer above, of research on post-socialist cities taking place in a true vacuum is a false one, as indeed Grubbauer presumably would be the first one to concede. Post-socialist urban studies do engage with the wider world, perhaps most notably in the sense that there is no lack of ideas imported from outside the pale. For, while critics of post-socialist urban studies might have a reason for portraying it as stubbornly empirical - Grubbauer (2012, p. 42) suggest that the field is characterised by "descriptive, ideal-type and often schematic post-socialist analysis" which "is inadequate to explain ... the particularities of place" - this must not be construed as the field being uninterested in what happens elsewhere. Thus, quite a few sets of ideas and concepts originating elsewhere have experienced a keen reception. Discussions on gentrification, gated communities, suburbanisation or inner city redevelopment are all themes that are familiar to students of the post-socialist city (Borén, Gentile 2007), as are informality (Tsenkova 2012) and the threats to public space (Stanilov 2007), which all belong to this category. Indeed, one of the core debates amongst specialists on socialist and post-socialist urbanism concerns the very nature of socialist/post-socialist cities themselves (e.g., French, Hamilton, eds. 1979; 
Bater 1980; Enyedi 1996; Szelenyi 1996; Gentile, Sjöberg 2006; Sýkora 2009; Hirt 2013). Are they similar to or a distinctly different species compared to the western counterparts? Is modernity and industrialisation a more important explanatory factor than is socialism and the subsequent move away from the centrally planned one-party state? Hence, it is explicitly comparative, suggesting a need to sample what is done elsewhere, at least empirically.

Yet, in post-socialist urban studies (Wiest 2012), as is often the case in urban studies more generally (Robinson 2003; McFarlane 2010), comparisons are not seldom implicit rather than explicit. Irrespective of which, if primarily an issue of imports, the impact on the wider literature is likely to be slim. At best, work on the post-socialist urban landscape will be used as an example of empirical work done, which is not the same as engaging with the findings reported at a more fundamental level. This is where the work listed by Marcińczak et al. (2014) has the potential of coming into its own. I will therefore briefly summarise the contents and approach of these three articles with respect to the extent they import ideas discussing these articles in order to illustrate my points about their explicit but also potential links to the wider project of urban studies.

Taken together, they illustrate different levels of ambition and potential, or a progression towards the potential goal of becoming part of and contributing to general urban theory. The first one, by Marcińczak, Musterd and Stępniak (2012), analyses social segregation in three Polish cities and hence tackles an issue that is no newcomer to urban studies, but which is only now reaching some critical mass within studies of post-socialist societies (e.g., Gentile 2003; Temelová et al. 2011; Marcińczak, Gentile, Stępniak 2013). Yet, it is noticeable that the article uses prior work from outside the region as a source of theory and methods only (sensibly and usefully so), added to which we find empirical results that could be used for comparative purposes. However, even if outlined at some length in the section on prior literature, the explicit comparison of outcomes is very limited; under the simple typology put to use here it qualifies as a case of imports.

The second article of this set of three, an introduction to a special issue of Cities on social and spatial change in Central and East European cities by Gentile, Tammaru and van Kempen (2012), focuses on heteropolitanisation. Defined as a process whereby a city moves into the direction of becoming more heterogeneous and more complex it clearly issues form prior literature (and hence is imported), namely from the Los Angeles school of urban theory. The term itself originates with Jencks (1993), to whom Los Angeles represents the true multi-ethnic and multi-cultural city, not least expressed in eclectic architectural styles, or hetero-architecture as he styles it. As Gentile and coauthors note, however, it is has barely been used outside that context, its potential thereby being a clean slate.

The heteropolis is an ideal type and so is its opposite number, the homopolis. "A pure-blooded socialist city can only be a homopolis", they note, "but a homopolis need not be socialist" (Gentile, Tammaru, van Kempen 2012, p. 293). Moving into post-socialism thus implies heteropolitanisation, albeit that speeds and the exact trajectories may well differ. In that sense it is very much an example of the type of research which Grubbauer (2012, p. 42) finds so 
problematic. But does that make it less worthwhile? In my view this represents the beginnings of building theory, conceptualisation after all typically being a necessary step in that direction (but concepts in themselves do not provide, only at most suggest, explanation or interpretation). Indeed, the authors selfconsciously assert that they set out "to provide a theoretical context" (Gentile, Tammaru, van Kempen 2012, p. 291) within which the transformations that constitute the transition from socialist to post-socialism and beyond can be set. In that sense, and somewhat ironically, it is very much a parallel to the course of action that Grubbauer herself outlines for moving beyond the impasse she claims to characterise our field.

As importantly, from the vantage point of the typology I use here, theirs is a case of importing a few concepts to the bare bones of which is added a considerable amount of meat. As such it allows not just for application to CEE cities as the title of their article implies, but also potentially beyond. True, the specifics of that particular region, primarily the $20^{\text {th }}$ century experiences these cities share, may not be easily transferable to other contexts, but the approach as such and its core dichotomy may well find fertile soil elsewhere. This only time will tell, the authors themselves stopping short of giving any clues as to the wider usefulness, if any, of their construct. In that sense it is not (yet) a case of successful, value-adding processing and assembly of imported intermediary ideas - such as the key concept of heteropolis - which subsequently could compete in the market for intellectual goods. Yet, the potential is there and if noted also outside the ranks post-socialist urbanist scholars it is not likely to be restricted to the category "yet another case study", this time from the unknown territories that used to be located behind the Iron Curtain.

The third and final contribution enlisted for the case of suggesting that post-socialist urban studies do indeed contribute to theory, the article by Sýkora and Bouzarovski (2012) is a still more clear-cut case of trying to move beyond the maze of case studies. Aiming at "offer[ing] a more explicit grounding of the theoretisation of urban change in post-communist cities" (p. 43), it sets out from the assumption that there is an underlying common logic to transition, and that this process of moving away from being socialist can be captured by reference to three major transformations, namely the transformation of the institutional set-up; of practices (be they political, economic, social or cultural) of individuals, firms and organisations; and that of the built environment ("transformation dynamics of urban change", p. 45). As such it manages to work around a number of polarised debates and accommodates processes of change that play out over different time horizons. Although it is not always self-evident what is an explanation and what is merely a consequence of something that is not accorded explanatory status, they provide much needed clarity with respect to key concepts that aspire to capture the processes that have unfolded before our eyes over the past quarter of a century.

The framework developed by Sýkora and Bouzarovski will no doubt prove helpful, as indeed there are already signs that it has done (e.g. Golubchikov, Badyina, Makhrova 2014). Even so, Grubbauer (2012, p. 51) finds it "too schematic and reductionist to understand the most intriguing and most challenging aspects of urban change under post-socialism: the interdependent nature of social and material change. ... This kind of analysis fails to address culture, 
meaning and agency". Fair enough, that might be the most interesting thing about post-socialism, but not necessarily the only one; besides, the priority that Grubbauer identifies is very much in the eye of the beholder as it is postulated rather than shown to be of critical importance. What Sýkora and Bouzarovski set out to do, on my reading, is rather to provide a context within which an analysis of the type their critic favours could be assessed and meaningfully related to society-wide phenomena. The fact that their model seems linear while "the social and material changes are not sequenced in the post-socialist city", but are rather "taking place simultaneously from the first days of the post-socialist era onwards" (Grubbauer 2012, p. 51) does not undermine the model as such.

The above goes to prove that this might be very useful to those of us who find "the hegemonic project of post-socialism" (Golubchikov, Badyina, Makhrova 2014 , p. 620) enduringly enthralling. But precisely because it aspires to provide a platform for theorisation for the benefit of post-socialist urbanists, it may be less attractive for those who do not primarily focus on Central and Eastern Europe. As Hörschelmann and Stenning (2008, p. 340) suggest with the field of post-socialist studies itself in mind, "[t]o locate one's work first within one of the many diverse postsocialist contexts and second in relation to a geographical subfield or conceptual strand either consigns one entirely to the margins of the discipline or evokes the interest only of those who also work in the area and/or who find it useful for illustrating the validity of general concepts".

The idea of multiple transformations has all the wherewithal of becoming a successful export, save that its empirical focal point may restrict its usefulness beyond the confines of the context which first saw it formulated. Most importantly, it tries to formulate a framework that can accommodate the very "diverse postsocialist contexts" that Hörschelmann and Stenning mention, indeed to transcend it, if you will. As for the possible lack of allure in other settings, this need not necessarily be the drawback as it may seem to be if we aspire to contributing to urban theory. For, also beyond the observation that the export success (or otherwise) of the multiple transformations framework is an empirical proposition that may or may not turn out to become true, the past decade and a half has seen a growing resentment with high urban theory itself. Instead of building on a select few paradigmatic cases, all drawn from a geographically very limited sample, increasingly strong concerns have been voiced that urban theory needs to become more inclusive, more truly globally relevant. What is more, there is an increasingly influential line of research that aspires to do just that, and which has arrived at the shores of the post-socialist countries as well. This is where I now turn.

\section{On a very different track? Enter post-colonialism}

"In my view, at least two features of this giant [post-Soviet] sphere are significant for currently constituted postcolonial studies: first, how extraordinarily postcolonial the societies of the former Soviet regions are, and, second, how extraordinarily little attention is paid to this fact."

Moore (2001, p. 114) 
Urban studies are disarmingly eclectic. This, no doubt, reflects the rich urban environments and the activities that infuse these very environments with life and dynamism. There is quite simply something for everyone to sample and to cherish. We need not think of the rapidly increasing number of people setting off on urban weekend breaks - a phenomenon which has seen a phenomenal increase over the past generation or so, not least in Europe - but also within the Ivory tower the multi-disciplinary character of urban studies is as good a witness as any to the vibrancy and manifold manifestations afforded by the urban setting.

Even so, over the past decade or so voices have increasingly been heard suggesting that this very richness is not reflected in urban theory. At least since the turn of the Millennium, scholars such as Roy (2009, 2011a, 2011b), Ong (2011) and Simone (2001) of worlding city fame and, perhaps more than anyone else, Robinson $(2002,2003,2006,2011)$ have admonished us to de-centre fashionable theories that privilege the Global North as the standard for assessing urban change and development, calling instead on us to embrace a more cosmopolitan view or at least one that takes comparisons more seriously (as is done e.g. by Simone 2010 and Myers 2011). At the bottom of this is an attempt to call into question the universalistic claims made on behalf of studies conducted on a select few exemplary cities, these prototypes of things to come typically being drawn from a small number of settings on either side of the Atlantic. The idea that Paris was the capital of the $19^{\text {th }}$ century (Benjamin [1935] 1969), or the capital of modernity (Harvey 2003), lives on to this day, yet for the importance of that city, and of London and Berlin, early on the search for the exemplary city migrated across the North Atlantic. Thus, as is well known, Chicago and Los Angeles have since assumed this role - and when challenged, New York (Halle 2003), Miami (Nijman 1997) or Las Vegas (Venturi et al. 1977; Gottdeiner, Collins, Dickens 1999) are more likely contenders than are places further afield. Indeed, we are building much of our theorising on a few singular cases rather than on the ordinary city which Robinson (2006) wants us to focus on. Building on yet extending the argument of Amin and Graham (1997), she argues that we should "allow all cities to be thought of as ordinary" (Robinson 2006, p. 108, emphasis added).

\section{Urban space: post-socialist = post-colonial?}

In the study of post-socialist urban space, this lop-sidedness of urban theory is as much noticeable by its absence as by its visible presence. Indeed, you may rightful ask, what has the study of the urban geographies of post-communist states to do with all of this? Also geographers who are inclined to take a serious look at urban sociology, or anthropological work, will have noted that, superficially at least, much of our output is articulated in terms privileging that specific set of circumstances which allow us to speak of post-socialist cities in the first place. That is, contemporary developments are at the heart of our debates and it informs our choice of phenomena to study. Hence, I would argue, the pronounced fascination with the empirical. Hence, the occasional eruption of debates on transition, transformation, path dependence and the prospects for 
path creation, of issues of convergence or divergence, or of when post-socialist cities no longer can be regarded as such but rather post-post-socialist. The dominance of case studies and empirical agendas, however, is quite noticeable (see, e.g., the list of articles upon which Kubeš 2013 bases his analysis of the literature). Therefore, we have to admit that Grubbauer (2012, p. 38) is not entirely off the mark in claiming that "research on post-socialist cities has yielded a rather closed body of literature".

Yet, as already noted the implied notion of research on post-socialist cities taking place in a true vacuum is a false one. Post-socialist urban studies do engage with the wider world, perhaps most notably in the sense that there is no lack of ideas imported from outside the pale, if selectively so. For, while critical area studies in the sense advocated by Robinson (2003), Gibson-Graham (2004) or Sidaway (2013), and Appadurai (1996, pp. 16-18) before them, ${ }^{2}$ has so far not really caught on, other sets of ideas have experienced a wide reception. We have already noted that gentrification, gated communities, segregation, suburbanisation, inner city redevelopment or informality have successfully entered the vocabulary of post-socialist urban studies. But so have, at a somewhat more elevated theoretical or conceptual level, neoliberalism-neoliberalisms-variegated neoliberalisation and post-colonial theory.

Why bother, then? If post-socialist urban studies are to make use of its potential, and in a sense extend the relevance and shelf-life of the work done, I sincerely believe that we need to address the concern that we represent "a rather closed body of literature", as Grubbauer has it. Cosy as this corner of the Ivory tower might be, if we are not to doom ourselves and the geographical area we focus on to academic marginality, we need to think more in terms of our contribution to the wider academic enterprise. We can do precisely that in the manner which Hörschelmann and Stenning (2008), Ferenčuhová (2012), Grubbauer and Kusiak (2012a) or Wiest (2012) suggest: by embracing the project of building a de-Westernised version of urban theory. This would be particularly worthwhile to the extent that Grubbauer and Kusiak (2012b, p. 14) are correct in asserting that dominant lines of research on the (post-)socialist city makes that very city "overly 'orientalized' as radically different and yet at the same time this very difference is interpreted as mere 'backwardness' within the Western paradigm of urban modernization". Yet, for reasons that will become apparent as I proceed, assuming a post-colonial stance would be but a partial solution, indeed a stop-gap type of measure.

In a review of what other areas of the world - other than those that provide the paradigmatic or exemplary cases, that is - can contribute to the wider project of urban studies, Roy (2009) identifies a number established theories the relevance of which potentially reaches well beyond the geographical point of origin. In the "new geographies of theory", she suggests, Latin America, South and East Asia are fertile sources of theory. Also Africa and the Middle East are seen as the repository of useful ideas that can inform a reconstituted

2 Implying, amongst other things, a shift from geopolitically motivated "trait geographies" to "process geographies", which in turn entails a focus on "the forms of movement, encounter, and exchange that confound the idea of bounded world-regions with immutable traits" (Roy 2009, p. 821). 
urban theory of the worlding sort; indeed, the empirical aspects of the term worlding, which Roy has done much to propagate (Roy 2009; Roy, Ong, eds. 2011), as applied to urban studies appears to originate with Simone's (2001) work on Africa (the concept itself being drawn from Spivak 1985, p. 235).

Central and Eastern Europe, for its part, is not even mentioned $;^{3}$ as such it is in keeping with the pattern "[a]n overwhelming majority of work in Englishspeaking geography ignores postsocialist contexts entirely" (Hörschelmann, Stenning 2008, p. 340), as is also typically the case not only in geography but also more generally (Moore 2001). Post-socialism, or its equivalent, enters somewhat obliquely in the shape of studies on China - such as, for instance, Shanghai being shaped by and having a role in shaping two generations of modernity - and other Asian (ex-)socialist societies, but not as a meaningful category in its own right. This is no reason, however, for not using the gains and insights issuing from other parts of the world with a view to enhancing our understanding of the geographical or substantive area we have in focus. Post-colonial theory, be it in the form of transnational scholarship (of which ordinary, yet worlding cities is but one expression), its rootedness in the everyday, its focus on indigenous rights and identity or simply in the form of an application of some of its core conceptual advances does have that potential. Think hybridity, ambivalence and in-betweenness; think resistance, appropriation and imitation; or think, as do Diener and Hagen (2013, p. 508), "coercion, co-optation and collaboration" and "the expansion of Russian/Soviet hegemony across much of Eurasia" which has its parallels to colonialism - and one may perhaps add, neo-colonialism - as typically understood. Seen in this way, there is an affinity between countries that emerge from socialism and those that emerge from colonialism: they all were part of empires one way or other making them subject to a centre somewhere else (for a review of the issues, see, e.g., Hladík 2011). And as has been shown by Jacobs (1996), neither the imperial centre nor the periphery of empire might really represent what it is typically taken to be.

On the back of the recommendations of Hörschelmann and Stenning (2008) and others, this is being done. Essentially a perspective which puts culture at the centre, it is no surprise that early discussions issue from literary studies and the like. Over time, however, the application of post-colonial theory has migrated into areas where the materiality of urban form holds sway, including for example the issue of why certain objects (such as buildings, statues) have been contested, and therefore may have been removed, while others have been left where they are, or to what extent developments observed can best be characterised as appropriation or mimicry (e.g. Lisiak 2009, 2010b).

This perspective can also be used to dig into the provenance of various concrete phenomena, the origin of which at first sight might appear foreign, even

\footnotetext{
A parallel case, albeit one where the socialist and post-socialist world explicitly appears, is reported by Sýkora and Stanilov (2014). This relates to a discussion of suburbs and suburbanisation by Harris (2010), in which post-socialism is either lumped together with the Global South or seen as a geography where developments "parallel the Global South [...] recent trends mix[ing] things up, juxtaposing people and types of development" (Harris 2010, p. 23).
} 
alien. By way of providing an example that has been embraced by post-colonial scholars, e.g., Grubbauer (2012), Hirt (2012, p. 11) claims that in Sofia gated communities "is a locally grounded phenomenon which not only reflects the vigor of post-socialist culture of privatism but may even represent a return to pre-twentieth century building traditions", namely those in vogue during Ottoman times. The parallel case of Warsaw, where a reference to that very same Ottoman legacy would be miserably out of place, has similarly been argued to be, in part at least, vested with local characteristics (Gąecki 2012). Another application is in comparative work (e.g. Wiest 2012), where post-colonial theory is said to allow for perspectives that are not hostage to universalising approaches which on a priori grounds assume a convergence towards a dominant Western model. While not explicitly comparative (nor for that matter explicitly post-colonial), the work of Adams (2010) on the spectacular state could not only be related to the built environment but conceivably also to the notion of arbitrage which Roy (2009) identifies as one of the contributions from East Asia and the gatekeeper role of the state that this implies in forming the everyday experiences of city dwellers. Indeed, with a view to theorising the link between the local context and the global, geographers have taken up the notion of assemblages and applied it to urban settings (e.g., McFarlane 2011; McCann, Roy, Ward 2013), with at least one application to post-socialism so far (Jayne, Ferenčuhová forthcoming). By way of a final example, the notion of hybrid spatialities, again inspired by post-colonial theory, has been used to uncover the manner in which the socialist legacy relates to post-socialist transition (Stenning 2005, p. 124; Golubchikov, Phelps 2011, p. 429); for instance, it has recently been argued that it takes on the role of "an infrastructure of neoliberalisation, conducive to capitalist process" (Golubchikov, Badyina, Makhrova 2014, p. 617).

The latter highlights a substantive area of post-socialist urban studies where post-colonial theory appears to have delivered, namely in cutting down to size the hegemony of neoliberalism as a paradigm for understanding the present (e.g. Stenning et al. 2010). Although a monolithic neoliberalism has long been challenged by notions such "actually existing neoliberalism" (Brenner, Theodore 2002) or "neoliberalisation" (Crang 2006), scholars inspired by post-colonial theory such as Parnell and Robinson (2012, p. 597) are adamant that a more thorough realignment of theory is needed: "[a] Southern (re)framing can contribute to a post-neoliberal theorization of urban processes by illuminating the multiple drivers of urban change". As Parnell and Robinson (2012, p. 595) go on to note, "the fact that a relatively small group of highly visible theorists tend, perfectly reasonably, to write about their own backyards" is a recipe for parochialism that needs to be put right. Following up on this line of reasoning, but criticising the tendency to use the Euro-American city in a unitary and universalising manner, Baptista (2013, p. 590) similarly argues that "current analytical overinvestment in neoliberalism may obscure important drivers of contemporary urbanization and that recourse to a diversity of concepts may be a more profitable line of inquiry", taking us to the "borderlands" (in this case Portugal) beyond the "heartlands" of urban theory, without therefore having to travel as far south as post-colonial theory admonishes us to do (a parallel argument can be found in Lisiak 2010a, p. 36, where Central European cities 
are categorised as "in-between peripheral"). Clearly, there is more to be done on this score, and Central and Eastern Europe is as good a battle ground as any. The work quoted above, focusing on "our" part of the world and taking a cue from post-colonial theory, may well be on to something despite the sense that also post-colonial theory is beyond its prime (e.g., Ong 2011).

Encouraging as all of this is, in two critical respects we are no better off than we were following up on Grubbauer's (2012) critique of the current standing of post-socialist urban studies. One relates to the Grubbauer and Kusiak's (2012a) own work: with the possible exception of the concluding chapter (Kusiak 2012), neither they nor the other authors contributing to their edited volume are strikingly successful in breaking out of the mould they identify. Rather they tend to further the dichotomy between socialist and capitalist - and by implication the "post-socialist difference" (Hörschelmann 2002) - which they critique (Grubbauer, Kusiak 2012b, p. 14). More importantly given the focus here, while useful ideas issuing from post-colonial theory are imported, there are preciously few signs as yet that successful re-exports are on the rise, let alone exports of goods produced to local, innovative designs that are received with open arms outside our band of scholars and which will change the course of urban theory. Time is of course an issue - much of the literature is quite recent - but two other factors may put spanners in the works.

The first one relates to the manner in which we choose to communicate our findings: it is rather silent or indirect as far as the wider contribution our work makes, or might make. It is rarely asked, for instance, in what sense do post-colonial contributions mark an improvement over what went before? Does a post-colonial reading of the removal or survival of tangible symbols in urban space (e.g., as in Lisiak 2009, 2010b) add something by way of new interpretation, for instance, to Czepczyńsk's (2008, ch. 4) discussion on post-communist landscape cleansing? Do post-colonialist readings of the urban landscape lay bare, in a more effective fashion than alternative approaches (of which there are plenty, e.g., Sýkora 1994; Smith 1996; Vendina 1998; Tosic 2003; Taşan-Kok 2006; Tsenkova 2006; Light, Young 2010; Hirt 2012, 2013; Pixová 2013), the interrelationship between social and spatial structures as Nawratek (2012, p. 7) claims? While many adherents of post-colonial theory may object to the very notion of science being cumulative, what this is all about is being able to offer something in addition to that which has already been done. This is particularly important in case we accept Moore's (2001, p. 124) somewhat inconvenient observation that all places can be considered post-colonial - no part of the world being unaffected at some point by the domination by non-local powers - and that we therefore should ask ourselves whether "postcolonial hermeneutics might add richness to studies of place or literature X, Y or Z". Shifting the focus from explanation to interpretation, and from high theory to the specifics of place, does not absolve urban scholars from being careful in not reinventing the wheel.

The second one concerns the nature of post-colonial theory itself: despite its roots in Marxist theory, it is an amalgam of concepts rather than a theory in the sense that it offers a coherent explanation of some phenomenon that is or can, in principle, be backed up by evidence. This is of course a conscious choice: post-colonial theory is primarily concerned with interpretation and the creation of meaning, and the agency that underwrites it. As such, it offers a 
perspective, and it offers concepts that can be applied, refined and extended, in the process yielding insights that would otherwise escape us. But because of this focus on interpretation and its limited purchase with respect to explaining why, as opposed to showing how, post-colonial theory is not very likely to help post-socialist studies punch above its weight as the fight over the high ground of urban theory moves into the next round. As the "generalizable claims of postcolonial theory", as Ong (2011, p. 9) has is, are not grounded in an urge to explain but to follow an interpretive logic, they cannot readily be put to a test. Indeed, or so Snochowska-Gonzales (2012, p. 720) claims, the focus on things cultural to the exclusion of things material does little to allow post-colonial theory to produce "a consistent narrative" in the first place, let alone one that can be made subject to verification. For this reason I would venture the proposition that it is no more likely to help us along than is that part of post-socialist urban studies which is not informed by post-colonial thinking.

Put differently, it is not surprising, therefore, that I have failed to find any major feedback, theoretical or otherwise, to the global body of post-colonial theory from the efforts described above. It may of course materialise in the future, but for now ours is a corner of urban studies which remains an importer. Let us hope, however, that we may live to see the findings of Golubchikov, Badyina, Makhrova (2014, p. 617) "reverberate much more broadly", as they explicitly expect. Again, only time will tell. The potential is there, but the manner it is communicated may equally well restrict its impact to those most closely concerned - us, the community of scholars trading under the post-socialist urban studies label.

As a corollary, I fail to see that post-socialist urban studies will become less of "a closed body of literature" by following the recommendations of those arguing in favour of post-colonial approaches - and I say so despite harbouring considerable sympathy for the project of cutting the notion of a globalising neoliberalism, or that of the paradigmatic city, down to size. But as long as we make use of these approaches only ("only") to inform the study of post-socialism, rather than using it as a means towards the end of enlightening the broader field of urban studies as Hörschelmann and Stenning (2008), and Musil (2005) before them, admonish us to do, we will guard the status quo and little else. Simply following our times, as expressed in a (necessary) willingness to engage with the ideas that originate elsewhere, is not enough. Instead, I challenge everyone - not just geographers - in post-socialist urban studies to consider how we can move beyond an "import-dependent model" of research, one that is not stuck at the receiving end.

\section{In lieu of a conclusion: a few options}

Essentially, what I have done this far is to ask whether post-colonial theory is an improvement on the current state of the art, and whether it has the potential to allow us to move beyond the status quo. This has entailed finding answers to two questions. First, do post-colonial approaches add to "standard" case study work in our field, that is contributing something that is novel relative what we are already capable of doing or finding out? Thus, does post-colonial theory have 
the potential to strengthen our knowledge of post-socialist cities and urbanism as a phenomenon, and not just providing "add-ons" with respect on how we should approach individual cases that we (legitimately) chose to study for their own sake? Secondly, can it help us advance our case relative urban theory as such? Will it, if I may continue the crude analogy with trade, allow us to move beyond importing theory for our own sake, in addition also allowing us to render intelligible the case studies we produce with consumers in export markets in mind? Will it allow us to engage in still more lucrative re-exports which, following value-adding refining, assembly or repackaging operations, may contribute to a reconstituted urban theory, the ultimate form of "foreign" market penetration? Or should we instead, as a third route forward, consider trying to start anew, launching locally designed and produced intellectual products that can inform or replace current urban theory in the international market place for ideas? Perhaps we should aim for our own widely recognised and respected brand (Poso, where the best in urban theory starts, anyone?).

On a more serious note, my provisional answer to the first question is that it indeed has that potential, but there are as yet surprisingly few cases where it does add in a substantial fashion. As to the second, I find it more doubtful, and then not because of its focus on "culture, meaning and agency" (Grubbauer 2012 , p. 51) per se, but rather because the interpretative focus implied does not seem conducive to creating something new that could speak back to current high theory in a decisive manner. Post-colonial theory as such may well be seen as such a challenge to urban theory of the kind the Los Angeles school represents, but its application to ex-socialist environments is not very likely to elevate it to new heights, if only for the simple reason that also influential work within the LA school shares many of methodological prescriptions that post-colonial theory offers (possibly most clearly seen in Soja 1996).

This in turn implies that one of a number of conceivable ways forward, more post-colonial theory, is not the answer to the challenge I just raised. Nor is the type of work that currently dominates our field, and which generated the critique that post-colonial theory was supposed to alleviate. So what are the options? One is to pick up some of the as yet loose ends of the debate on post-colonialism and neoliberalism, in the form Ong (2011) sets forth. That is, a focus on worlding - the notion that places become ever more global but in locally or regionally differentiated ways - but within a post-postcolonial framework (Parnell, Robinson 2012; compare McCann, Roy, Ward 2013 on policy transfer). Another is to make more (of) comparisons as might be available to us. Robinson, in her Ordinary Cities (2006, ch. 3), provides several ideas, but we need not necessarily turn to the Global South to find useful thinking on the subject. Early attempts to compare different parts of the socialist or immediately post-socialist realms - think China and Vietnam or developing socialist countries more generally relative what was then typically labelled Eastern Europe (e.g., Murray, Szelenyi 1984; Thrift, Forbes 1986; Chan 1994; Sjöberg 1999; Zhang, Zhao 2003) - fall to this category, but so do some more recent projects that explicitly compare post-socialist cities to cities elsewhere, for instance on large scale housing estates (van Kempen et al. 2005; Rowlands, Musterd, van Kempen, eds. 2009) or new demographic realities and shrinking cities (e.g., Buzar et al. 2007; Wiechmann, Pallagst 2012; Hospers 2013; Bernt 
et al. 2014). Others may take a longer historical perspective and in particular two excellent works of this sort provide ample food for thought on the why and how of comparisons across (sets of) cities which at first sight seem sui generis: Ruble's Second Metropolis (2001) and Wasserstrom's (2007) spirited yet balanced argument in favour of comparing Shanghai with Budapest.

Yet a third option, now following the import/re-export track, could be to marry our standard empirical concerns with some other body of theory that in turn could be used to provide novel applications and insights. Given that the contribution of post-colonial theory to the symbolic and material aspects of the urban build environment has been brought up previously, why not try some other approach to landscapes? What could come out of an attempt, for instance, to transplant the ideas of Mitchell (e.g. 2008, 2013) from rural California, or say Hannah's (2013) on attention and the phenomenological politics of landscape, to its (post-)socialist urban equivalent? What could be learnt about the possibilities and constraints of Mitchell's (2013) dual notion of (anti-) revolutionary landscapes when applied to the rather different setting that the ex-socialist cities of Europe afford? It has been suggested, after all, that those ideas are relevant to all sorts of settings, from "the magic figures of 1968, 1989 and 1999 in the landscapes of Paris and Prague, Berlin and Beijing, London and Seattle..., but also the motley string of revolts of the more recent past" across the Middle East and the former socialist countries (Mels, Germundsson 2013, p. 213).

There are a host of other phenomena over and above urban landscapes which combine a pre-existing post-socialist urban literature with a potential for using existing theory from outside the region to enhance our ability to understand and explain current developments, be they transitory or more permanent. Thus, the potential for finding a path towards a (post-)socialist urban geography that punches above its weight is there. However, to do so a more explicit and systematic use of the core tools of social science research - theories and models - is desirable, quite possibly necessary if for no other reason than to establish an effective means of communication across the sub-fields of urban studies. As things now stand, in quite a few cases, if not the majority, use rarely extends beyond simple (if at times very effective) comparisons along the continuum similarity-difference, basic conceptualisation (e.g., definitions) and typologies, while deep engagement with theory is not particularly visible. And, as noted by Großmann et al. (2013, p. 223), there is a clear gain in doing precisely that. For while Grubbauer (2012) is clearly off the mark in depicting our field as isolated and inward looking, she does have a point as far as the empiricism is concerned. Indeed, as yet we do not see much that amounts to home-grown theory that could, combined with our own strong empirics and perhaps with the help of additional imported theory, build a solid platform from which to proceed. Somewhat ironically perhaps, when such theory does surface, as is arguably the case with the intra-urban landscapes of priorities framework, which has been applied to both socialist and post-socialist urban environments (Gentile 2003, 2004; Leetmaa, Tammaru, Anniste 2009; Gentile, Sjöberg 2006, 2010, 2013; Liu, He, Wu 2012; Madrazo, van Kempen 2012), it is based on the unique qualities that central planning bestowed upon the cities we are so keen to study. The potential for striking a chord with non-area specialists focusing 
on other substantive or geographical areas than the socialist and post-socialist world appears minimal.

Against the above, it is noticeable yet not particularly surprising that we are still to see anyone successfully taking the big issue - that of contributing to high theory (e.g. as represented by the Los Angeles school of urbanism) - by the horns. As far as our options are concerned, therefore, a further and a most desirable route forward is to try to repeat what post-colonial theory originally did: design an entirely new framework that shifts the focus in previously unanticipated ways which may replace or displace the currently dominant ways of thinking. This would be tall order indeed, and I would think there is a much easier, if less revolutionary, way of achieving the end of influencing the dominant schools of thought in contemporary urban theory. That is to break out of that mould which effectively restricts the relevance of our work to our closest colleagues, those who engage in post-socialist urban studies for the sake of improving our understanding of what is happening in the ex-socialist world. This is, let me be clear on this point, a most honourable and worthwhile pursuit, but it is not going to endear us to the rest of the urban studies community. And in order to reach out to them we cannot in effect pretend that our chosen objects of study are cases onto themselves. In order to avoid "evok[ing] the interest only of those who also work in the area and/or who find it useful for illustrating the validity of general concepts" (Hörschelmann, Stenning 2008, p. 340) we have to find a balance between our legitimate interest in post-socialist urban environments for their own sake and the lessons of a wider import that can be derived from them. To do so we need to change our way of thinking about urban theory, to move beyond seeing it as a mere source of good ideas (as it often is) to be imported with a view to enhancing our understanding of what goes on before our eyes in "our" chosen part of the world. We need to report back to that theory, to those imported ideas, boldly but not necessarily impudently. This is as much a way of communicating as a frame of mind. Hence, it would not imply a major paradigmatic shift in the way we look at the world or how we go about our work, just some fine-tuning - and a lot of patience, to be sure.

This paper originates as a keynote address to the $5^{\text {th }}$ International Urban Geographies of Post-Communist States Conference, held in Tbilisi, 11-13 September 2013. Helpful inputs from Matthias Bernt, Mariusz Czepczyński, Slavomíra Ferenčuhová, Michael Gentile, Daniel Göler, Oleg Golubchikov, Annegret Haase, Szymon Marcińczak, Olga Medvedkov, Madlen Pilz, Joseph Salukvadze, Luděk Sýkora and Craig Young, and not least by the referees and editors of the journal, at various stages of this work are gratefully acknowledged. While their input has been of critical importance in drafting this contribution, none of them can of course be held responsible for the final outcome; it goes without saying that any such responsibility rests entirely with the author. 


\section{References:}

ADAMS, L.L. (2010): The Spectacular State: Culture and National Identity in Uzbekistan. Duke University Press, Durham, NC, 242 pp.

AMIN, A., GRAHAM, S. (1997): The ordinary city. Transactions of the Institute of British Geographers, NS, 22, No. 4, pp. 411-429.

APPADURAI, A. (1996): Modernity at Large: Cultural Dimensions of Globalization. University of Minnesota Press, Minneapolis, $248 \mathrm{pp}$.

BAPTISTA, I. (2013): The travels of critiques of neoliberalism: urban experiences for the "borderlands". Urban Geography, 34, No. 5, pp. 590-611.

BATER, J.H. (1980): The Soviet City: Ideal and Reality. Edward Arnold, London, 196 pp.

BECKER, T. (1989): Academic Tribes and Territories: Intellectual Enquiry and the Culture of Disciplines. Open University Press, Milton Keynes, 200 pp.

BENJAMIN, W. ([1935] 1969): Paris: capital of the Nineteenth Century. Perspecta 12, pp. 163-172.

BERNT, M., HAASE, A., GROßMANN, K., COCKS, M., COUCH, C., CORTESE, C., KRYSZTOFIK, R. (2014): How does(n't) urban shrinkage get onto the agenda? Experiences from Leipzig, Liverpool, Genoa and Bytom. International Journal of Urban and Regional Research, 38, No. 5, pp. 1749-1766.

BORÉN, T., GENTILE, M. (2007): Metropolitan processes in post-communist states: an introduction. Geografiska Annaler: Series B, Human Geography, 89, No. 2, pp. 95-110.

BRENNER, N., THEODORE, N. (2002): Cities and the geographies of "actually existing neoliberalism". Antipode, 34, No. 3, pp. 349-379.

BUZAR, S., OGDEN, P., HALL, R., HAASE, A., KABISCH, S., STEINFÜHRER, A. (2007): Splintering urban populations: emergent landscapes of reurbanisation in four European cities. Urban Studies, 44, No. 4, pp. 651-677.

CHAN, K.W. (1994): Cities with Invisible Walls: Reinterpreting Urbanization in Post-1949 China. Oxford University Press, New York, $193 \mathrm{pp}$.

CRANG, N. (2006): From neoliberalism to neoliberalisation: consolations, confusions, and necessary illusions. Environment and Planning A, 38, No. 1, pp. 1-6.

CZEPCZYNSKI, M. (2008): Cultural Landscapes of Post-socialist Cities: Representation of Powers and Needs. Ashgate, Aldershot, $224 \mathrm{pp}$.

DIENER, A.C., HAGEN, J. (2013): From socialist to post-socialist cities: narrating the nation through urban space. Nationalities Papers, 41, No. 4, pp. 487-514.

ENYEDI, G. (1996): Urbanization under socialism. In: Andrusz, G., Harloe, M., Szelenyi, I. (eds): Cities after Socialism: Urban and Regional Change and Conflict in Post-Socialist Societies. Blackwell, Oxford, pp. 100-118.

FERENČUHOVÁ, S. (2012): Urban theory beyond the "East/West divide"? Cities and urban research in postsocialist Europe. In: Edensor, T., Jayne, M. (eds): Urban Theory beyond the West: a World of Cities. Routledge, London, pp. 65-74.

GADECKI, J. (2012): Gating Warsaw: enclosed housing estates and the aesthetics of luxury. In: Grubbauer, M., Kusiak, J. (eds): Chasing Warsaw: Socio-Material Dynamics of Urban Change since 1990. Campus, Frankfurt am Main, pp. 109-132.

GENTILE, M. (2003): Residential segregation in a medium-sized post-Soviet city: Ust'-Kamenogorsk, Kazakhstan. Tijdschrift voor Economische en Sociale Geografie, 94, No. 5, pp. 589-605.

GENTILE, M. (2004): Divided post-Soviet small cities? Residential segregation and urban form. Iin: Leninogorsk, Zyryanovsk: Kazakhstan. Geografiska Annaler: Series B, Human Geography, 86, No. 2, pp. 117-136.

GENTILE, M., SJÖBERG, Ö. (2006): Intra-urban landscapes of priority: the Soviet legacy. Europe-Asia Studies, 58, No. 5, pp. 701-729.

GENTILE, M., SJÖBERG, Ö. (2010): Spaces of priority: the geography of Soviet housing construction in Daugavpils, Latvia. Annals of the Association of American Geographers, 100, No. 1, pp. 112-136.

GENTILE, M., SJÖBERG, Ö. (2013): Housing allocation under socialism: the Soviet case revisited. Post-Soviet Affairs, 29, No. 2, pp. 173-195. 
GENTILE, M., TAMMARU, T., VAN KEMPEN, R. (2012): Heteropolitanization: social and spatial change in Central and East European cities. Cities, 29, No. 5, pp. 291-299.

GIBSON-GRAHAM, J.K. (2004): Area studies after poststructuralism. Environment and Planning A, 36, No. 3, pp. 405-419.

GOLUBCHIKOV, O., PHELPS, N.A. (2011): The political economy of place at the post-socialist urban periphery: governing growth on the edge of Moscow. Transactions of the Institute of British Geographers, NS, 36, No. 3, pp. 425-440.

GOLUBCHIKOV, O., BADYINA, A., MAKHROVA, A. (2014): The hybrid spatialities of transition: capitalism, legacy and uneven urban economic restructuring. Urban Studies, 51, No. 4, pp. 617-633.

GOTTDIENER, M., COLLINS, C.C., DICKENS, D.R. (1999): Las Vegas: The Social Production of the All-American City. Blackwell, Malden, MA, 304 pp.

GROßMANN, K., BONTJE, M., HAASE, A., MYKHENKO, V. (2013): Shrinking cities: notes for the further research agenda. Cities, 35, pp. 221-225.

GRUBBAUER, M. (2012): Toward a more comprehensive notion of urban change: linking post-socialist urbanism and urban theory. In: Grubbauer, M., Kusiak, J. (eds): Chasing Warsaw: Socio-Material Dynamics of Urban Change since 1990. Campus, Frankfurt am Main, pp. 35-60.

GRUBBAUER, M., KUSIAK, J., eds. (2012a): Chasing Warsaw: Socio-Material Dynamics of Urban Change since 1990. Campus, Frankfurt am Main, $336 \mathrm{pp}$.

GRUBBAUER, M., KUSIAK, J. (2012b): Introduction: chasing Warsaw. In: Grubbauer, M., Kusiak, J. (eds): Chasing Warsaw: Socio-Material Dynamics of Urban Change since 1990. Campus, Frankfurt am Main, pp. 9-24.

HALLE, D. (2003): The New York and Los Angeles schools. In: Halle, D. (ed.): New York and Los Angeles: Politics, Society, and Culture - a Comparative View. University of Chicago Press, Chicago, pp. 1-46.

HARRIS, R. (2010): Meaningful types in a world of suburbs. In: Clapson, M., Hutchison, R. (eds): Suburbanization in Global Society. Emerald, Bingley, pp. 15-47.

HARVEY, D. (2003): Paris, Capital of Modernity. Routledge, London, $372 \mathrm{pp}$.

FRENCH, R.A., HAMILTON, F.E. I., eds. (1979): The Socialist City: Spatial Structure and Urban Policy. Wiley, Chichester, $541 \mathrm{pp}$.

HANNAH, M.G. (2013): Attention and the phenomenological politics of landscape. Geografiska Annaler: Series B, Human Geography, 95, No. 3, pp. 235-250.

HIRT, S. (2012): Iron Curtains: Gates, Suburbs and Privatization of Space in the PostSocialist City. Wiley-Blackwell, Oxford, $239 \mathrm{pp}$.

HIRT, S. (2013): Whatever happened to the (post)socialist city? Cities, 32, No. S1, pp. S29-S38.

HLADÍK, R. (2011): A theory's travelogue: post-colonial theory in post-socialist space. Teorie vědy, 33, No. 4, pp. 561-590.

HÖRSCHELMANN, K. (2002): History after the end: post-socialist difference in a (post)modern world. Transactions of the Institute of British Geographers, NS, 27, No. 1, pp. 52-66.

HÖRSCHELMANN, K., STENNING, A. (2008): Ethnographies of postsocialist change. Progress in Human Geography, 32, No. 3, pp. 339-361.

HOSPERS, G.-J. (2013): Coping with shrinkage in Europe's cities and towns. Urban Design International, 18 , No. 1, pp. 78-89.

JACOBS, J.M. (1996): Edge of Empire: Postcolonialism and the City. Routledge, London, $193 \mathrm{pp}$.

JAYNE, M., FERENČUHOVÁ, S. (forthcoming): Comfort, identity and fashion in the postsocialist city: materialities, assemblages and context. Journal of Consumer Culture DOI $10.1177 / 1469540513498613$.

JENCKS, C. (1993): Heteropolis: Los Angeles, the Riots and the Strange Beauty of HeteroArchitecture. Academy Editions, London, $144 \mathrm{pp}$.

KUBEŠ, J. (2013): European post-socialist cities and their near hinterland in intra-urban geography literature. Bulletin of Geography, Socio-Economic Series, 19, pp. 19-43.

KUSIAK, J. (2012): The cunning chaos and its orders: a taxonomy of urban chaos in post-socialit Warsaw and beyond. In: Grubbauer, M., Kusiak, J. (eds): Chasing Warsaw: Socio-Material Dynamics of Urban Change since 1990. Campus, Frankfurt am Main, pp. 291-320. 
LEETMAA, K., TAMMARU, T., ANNISTE, K. (2009): From priority-led to market-led suburbanisation in a post-communist metropolis. Tijdschrift voor Economische en Sociale Geografie, 100, No. 4, pp. 436-453.

LIGHT, D., YOUNG, C. (2010): Reconfiguring socialist urban landscapes: the "left-over" spaces of state-socialism in Bucharest. Human Geographies, 4, No. 1, pp. 5-16.

LISIAK, A. (2009): Disposable and usable pasts in Central European cities. Culture Unbound, 1, pp. 431-452.

LISIAK, A. (2010a): Urban Cultures in (Post)Colonial Central Europe. Purdue University Press, West Lafayette, IN, 232 pp.

LISIAK, A. (2010b): The making of (post)colonial cities in Central Europe. CLCWeb: Comparative Literature and Culture, 12 , No. 1, art. 3.

LIU, Y., HE, S., WU, F. (2012): Housing differentiation under market transition in Nanjing, China. Professional Geographer, 64, No. 4, pp. 554-571.

MADRAZO, B., VAN KEMPEN, R. (2012): Explaining divided cities in China. Geoforum, 43, No. 1, pp. 158-168.

MARCIŃCZAK, S., GENTILE, M., STEPNIAK, M. (2013): Paradoxes of (post)socialist segregation: metropolitan sociospatial divisions under socialism and after in Poland. Urban Geography, 34, No. 3, pp. 327-352.

MARCIŃCZAK, S., GENTILE, M., RUFAT, S., CHELCEA, L. (2014): Urban geographies of hesitant transition: tracing socioeconomic segregation in post-Ceauşescu Bucharest. International Journal of Urban and Regional Research, 38, No. 4, pp. 1399-1417.

MARCIŃCZAK, S., MUSTERD, S., STEPPNIAK, M. (2012): Where the grass is greener: social segregation in three major Polish cities at the beginning of the $21^{\text {st }}$ century. European Urban and Regional Studies, 19, No. 4, pp. 383-403.

MCCANN, E., ROY, A., WARD, K. (2013): Assembling/wordling cities. Urban Geography, 34 , No. 5, pp. 581-598.

MCFARLANE, C. (2010): The comparative city: knowledge, learning, urbanism. International Journal of Urban and Regional Research, 34, No. 4, pp. 725-742.

MCFARLANE, C. (2011): Assemblage and critical urbanism. City, 15, No. 2, pp. 204-224.

MELS, T., GERMUNDSSON, T. (2013): Figures in the revolutionary landscape: an introduction. Geografiska Annaler: Series B, Human Geography, 95, No. 3, pp. 213-218.

MITCHELL, D. (2008): New axioms for reading the landscape: paying attention to political economy and social justice. In: Wescoat, J.L., jr, Johnston, D.M. (eds): Political Economies of Landscape Change: Places of Integrative Power. Springer, Dordrecht, pp. 29-50.

MITCHELL, D. (2013): Labour's geography and geography's labour: California as an (anti-)revolutionary landscape. Geografiska Annaler: Series B, Human Geography, 95, No. 3, pp. 219-233.

MOORE, D.C. (2001): Is the post- in postcolonial the post- in post-Soviet? Toward a global postcolonial critique. PMLA, 116, No. 1, pp. 111-128.

MURRAY, P., SZELENYI, I. (1984): The city in the transition to socialism. International Journal of Urban and Regional Research, 8, No. 1, pp. 89-107.

MUSIL, J. (2005): Why socialist and post-socialist cities are important for forward looking urban studies. Paper prepared for the conference Forward look on urban science, Helsinki, 26-28 May.

MYERS, G. (2011): African Cities: Alternative Visions of Urban Theory and Practice. Zed, London, $242 \mathrm{pp}$.

NAWRATEK, K. (2012): Urban landscape and the postsocialist city. CLCWeb: Comparative Literature and Culture, 14 , No. 3, art. 10.

NIJMAN, J. (1997): Globalization to a Latin beat: the Miami growth machine. Annals of American Academy of Political and Social Sciences, 551, pp. 164-177.

ONG, A. (2011): Introduction: worlding cities, or the art of being global. In: Roy, A., Ong, A. (eds): Worlding Cities: Asian Experiments and the Art of Being Global. Wiley-Blackwell, Oxford, pp. 1-26.

PARNELL, S., ROBINSON, J. (2012): (Re)theorizing cities from the global South: looking beyond neoliberalism. Urban Geography, 33, No. 4, pp. 593-617.

PIXOVÁ, M. (2013): Spaces of alternative culture in Prague in a time of political-economic changes of the city. Geografie, 118, No. 3, pp. 221-242. 
ROBINSON, J. (2002): Global and world cities: a view from off the map. International Journal of Urban and Regional Research, 26, No. 3, pp. 513-554.

ROBINSON, J. (2003): Postcolonizing geography: tactics and pitfalls. Singapore Journal of Tropical Geography, 24, No. 3, pp. 273-289.

ROBINSON, J. (2006): Ordinary Cities: Between Modernity and Development. Routledge, London, $204 \mathrm{pp}$.

ROBINSON, J. (2011): Cities in a world of cities: the comparative gesture. International Journal of Urban and Regional Research, 35, No. 1, pp. 1-23.

ROWLANDS, R., MUSTERD, S., VAN KEMPEN, R., eds. (2009): Mass Housing in Europe: Multiple Faces of Development, Change and Response. Palgrave Macmillan, Basingstoke, $285 \mathrm{pp}$.

ROY, A. (2009): The $21^{\text {st }}$-century metropolis: new geographies of theory. Regional Studies, 43 , No. 6 , pp. $819-830$.

ROY, A. (2011a): Urbanisms, worlding practices and the theory of planning. Planning Theory, 10, No. 1, pp. 6-15.

ROY, A. (2011b): Conclusion. Postcolonial urbanism: speed, hysteria, mass dreams. In: Roy, A., Ong, A. (eds): Worlding Cities: Asian Experiments and the Art of Being Global. WileyBlackwell, Oxford, pp. 307-335.

ROY, A., ONG, A., eds. (2011): Worlding Cities: Asian Experiments and the Art of Being Global. Wiley-Blackwell, Oxford, 352 pp.

RUBLE, B.A. (2001): Second Metropolis: Pragmatic Pluralism in Gilded Age Chicago, Silver Age Moscow, and Meiji Osaka. Cambridge University Press, Cambridge, 464 pp.

SIDAWAY, J.D. (2013): Geography, globalization, and the problematic of area studies. Annals of the Association of American Geographers, 103, No. 4, pp. 984-1002.

SIMONE, A. (2001): On the worlding of African cities. African Studies Review, 44, No. 2, pp. 15-41.

SIMONE, A. (2010): City Life from Jakarta to Dakar: Movements at the Crossroads. Routledge, London, $403 \mathrm{pp}$.

SJÖBERG, Ö. (1999): Shortage, priority and urban growth: towards a theory of urbanisation under central planning. Urban Studies, 36, No. 13, pp. 2217-2236.

SMITH, D.M. (1996): The socialist city. In: Andrusz, G., Harloe, M., Szelenyi, I. (eds): Cities after Socialism: Urban and Regional Change and Conflict in Post-Socialist Societies. Blackwell, Oxford, pp. 70-99.

SNOCHOWSKA-GONZALES, C. (2012): Post-colonial Poland - on an unavoidable misuse. East European Politics and Societies, 26, No. 4, pp. 708-723.

SOJA, E.W. (1996): Thirdspace: Journeys to Los Angeles and Other Real-and-Imagined Places. Blackwell, Oxford, 334 pp.

SPIVAK, G.C. (1985): Three women's texts and a critique of imperialism. Critical Inquiry, 12 , No. 1, pp. 235-261.

STANILOV, K. (2007): Democracy, market, and public space in the transitional societies of Central and Eastern Europe. In: Stanilov, K. (ed.): The Post-Socialist City: Urban Form and Space Transformations in Central and Eastern Europe after Socialism. Springer, Dordrecht, pp. 269-283.

STENNING, A. (2005): Post-socialism and the changing geographies of the everyday in Poland. Transactions of the Institute of British Geographers, NS, 30, No. 1, pp. 113-127.

STENNING, A., SMITH, A., ROCHOVSKÁ, A., ŚWIĄTEK, D. (2010): Domesticating NeoLiberalism: Spaces of Economic Practice and Social Reproduction in Post-Socialist Cities. Wiley-Blackwell, Oxford, 304 pp.

SÝKORA, L. (1994): Local urban restructuring as a mirror of globalisation processes. Urban Studies, 31, No. 7, pp. 1149-1166.

SÝKORA, L. (2009): Post-socialist cities. In: Kitchin, R., Thrift, N. (eds): International Encyclopedia of Human Geography, 8, Elsevier, Oxford, pp. 387-395.

SÝKORA, L., BOUZAROVSKI, S. (2012): Multiple transformations: conceptualising the postcommunist urban transition. Urban Studies, 49, No. 1, pp. 43-60.

SÝKORA, L., STANILOV, K. (2014): The challenge of postsocialist suburbanization. In: Stanilov, K., Sýkora, L. (eds): Urban Decentralization in Postsocialist Central and Eastern Europe. Wiley-Blackwell, Oxford, 1-23 pp. 
SZELENYI, I. (1996): Cities under socialism - and after. In: Andrusz, G., Harloe, M., Szelenyi, I. (eds): Cities after Socialism: Urban and Regional Change and Conflict in Post-Socialist Societies. Blackwell, Oxford, pp. 286-317.

TAŞAN-KOK, T. (2006): Institutional and spatial change. In: Tsenkova, S., Nedović-Budić, Z. (eds): The Urban Mosaic of Post-Socialist Europe: Space, Institutions and Policy. PhysicalVerlag, Heidelberg, pp. 51-70.

TEMELOVÁ, J., NOVÂK, J., OUŘEDNÍČEK, M., PULDOVÁ, P. (2011): Housing estates in the Czech Republic after socialism: various trajectories and inner differentiation. Urban Studies, 48, No. 9, pp. 1811-1834.

THRIFT, N., FORBES, D. (1986): The Price of War: Urbanization in Vietnam, 1954-85. Allen and Unwin, London, $188 \mathrm{pp}$.

TOSICS, I. (2003): City Development in Central and Eastern Europe since 1990: the impacts of internal forces. In: Hamilton, F.E.I., Dimitrowska-Andrews, K., Pichler-Milanovic, N. (eds): Transformation of Cities in Central and Eastern Europe: Towards Globalisation. United Nations University Press, Tokyo, pp. 44-78.

TSENKOVA, S. (2006): Beyond transitions: understanding urban change in post-socialist cities. In: Tsenkova, S., Nedović-Budić, Z. (eds): The Urban Mosaic of Post-Socialist Europe: Space, Institutions and Policy. Physica-Verlag, Heidelberg, pp. 22-50.

TSENKOVA, S. (2012): Urban planning and informal cities in Southeast Europe. Journal of Architectural and Planning Research, 29, No. 4, pp. 292-305.

VAN KEMPEN, R., DEKKER, K., HALL, S., TOSICS, I., eds. (2005): Restructuring Large Housing Estates in Europe. Polity, Bristol, 392 pp.

VENDINA, O.I. (1998): Transformation processes in Moscow and intra-urban stratification of population. GeoJournal, 42, No. 4, pp. 349-363.

VENTURI, R., SCOTT BROWN, D., IZENOUR, S. (1977): Learning from Las Vegas: The Forgotten Symbolism of Architectural Form. $2^{\text {nd }}$ edn. MIT Press, Cambridge, MA, 192 pp.

WASSERSTROM, J. N. (2007): Is global Shanghai "good to think"? Thoughts on comparative history and post-socialist cities. Journal of World History, 18, No. 2, pp. 199-234.

WIECHMANN, T., PALLAGST, K.M. (2012): Urban shrinkage in Germany and the USA: a comparison of transformation patterns and local strategies. International Journal of Urban and Regional Research, 36, No. 2, pp. 261-280.

WIEST, K. (2012): Comparative debates in post-socialist urban studies. Urban Geography 33, No. 6, pp. 829-849.

ZHANG, L., ZHAO, S. X. (2003): Reinterpretation of China's under-urbanization: a systemic perspective. Habitat International, 27, No. 3, pp. 459-483.

\section{Shrnutí}

\section{PŘÍPADY SAMY PRO SEBE? TEORIE A VÝZKUM POST-SOCIALISTICKÉHO MĚSTSKÉHO PROSTŘEDÍ}

Studium socialistických a post-socialistických měst je v širším rámci urbánních studií dobře etablovanou specializovanou tematikou výzkumu. Ve stejné míre je to patrné také $\mathrm{v}$ rámci geografie, jako jedné z vědních disciplín, které se tímto mezioborovým nebo spíše mnoho-oborovým tématem zabývají. Přestože se příspěvek geografů v rámci studií post-socialistických měst může pochlubit značnou vitalitou, vyjádřenou např́íklad velkým objemem provedeného výzkumu, z něhož si velká část našla cestu do významných časopisů, dopad jejich práce na širší pole urbánních studií neodpovídá množství ani významu změn, ke kterým došlo po roce 1989, ani objemu publikovaných výzkumů. Celá výzkumná oblast zaostává z hlediska dopadu za svými možnostmi a jeho viditelnost mimo úzký prostor vědeckých komunit zaměřených na výzkum socialistických či post-socialistických měst tak zůstává, i přes nedávná tvrzení o opaku, prakticky minimální. To potvrzují i autoži post-koloniálního zaměření, kteří se shodují, že pokud se geografický výzkum post-socialistických měst chce výrazně posunout kupředu, musí se zbavit své údajné omezenosti, dominance empiricismu a oddanosti hegemonním proudům západních urbánních studií. 
Článek se snaží zhodnotit tato tvrzení v širším kontextu, přičemž upozorňuje, že zatímco některé zmíněné problémy pramení nepochybně ze zpo̊sobu, jakým urbánní geografové provádějí a uveřejňují výzkum post-socialistických měst, větší přimknutí k post-koloniální teorii dost možná nemusí být ideální cestou vpřed. Důvody pro tuto obezřetnost jsou v podstatě dva. Post-koloniální teorie jednak zatím neprokázala, zda představuje oproti tradičním přístupům ve vztahu $\mathrm{k}$ výzkumu post-socialistických měst zřetelné zlepšení, jednak je to i její vlastní náchylnost $\mathrm{k}$ některým problémům, které ve výsledku přispívají $\mathrm{k}$ nedostatečnému vlivu urbánních studií post-socialistických měst. Pokud bychom si mohli vypůjčit terminologii mezinárodního obchodu, obor se i s jejich přičiněním stává náchylným $\mathrm{k}$ vnějším vlivưm prostřednictvím konceptuálních „importů“, což je v protikladu s tvrzením a záměrem kritiků z post-koloniálních řad.

Tak jako tak, ani jedna akademická skupina dosud nebyla př́liš úspěšná ve svých pokusech zvýšit dopad výzkumu post-socialistických měst na širší pole urbánních studií nebo snad dokonce ovlivnit dominantní přístupy urbánní teorie (at již tyto pramenní z tradičních konceptů nebo jsou přímo inspirovány post-koloniálními přístupy).

Jinými slovy, schopnost této skupinu autorů „exportovat“ jejich myšlenky a zjištění zůstává přinejmenším slabá. Přestože tento stav může v budoucnu doznat změn, tato studie zastává názor, že ke zlepšení situace pravděpodobně nemůže dojít, pokud výzkumníci post-socialistických měst nevynaloží značné úsilí na vyřešení problémů spojených s aplikací této teorie (např. schopnost „exportovat“ myšlenky a využití), namísto jejího prostého využívání v současné podobě (,importování“ konceptů a konstrukcí a jejich aplikace na post-socialistické prostředí). Přestože využívání post-koloniální teorie je legitimní a užitečné (opačná tendence, tedy uzavírání před vnějšími vlivy by pravděpodobně byla kontraproduktivní), teoreticky inspirované případové studie nestačí $\mathrm{k}$ tomu, aby výzkum post-socialistických měst zvýšil svůj akademický dopad. K takovému účelu je potřeba zvážit dostupné možnosti. Ty zahrnují například potenciální zásahy do způsobu, jakým je výzkum obhájen ve vztahu k současnému stavu poznání, nebo hledání možností, jak zdokonalit importované koncepty pro využití v jejich novém kontextu. Další alternativou by dokonce mohlo být vytvoření nové teorie, která by dokázala přesáhnout specifickou povahu počátečních post-socialistických měst.

Author's affiliation: Stockholm School of Economics, PO Box 6501, SE-113 83 Stockholm, Sweden; e-mail orjan.sjoberg@hhs.se.

Initial submission, 20 December 2013; final acceptance 3 October 2014.

\section{Please cite this article as:}

SJÖBERG, Ö. (2014): Cases onto themselves? Theory and research on ex-socialist urban environments. Geografie, 119, No. 4, pp. 299-319. 